\section{7）硫酸バリウムの性能評価（第二報）流動硫酸バリウ ムの性能評価について}

名大分院放射線科 広 住 治夫
井 関 昭 夫

消化管造影剤としての硫酸バリウムは最近製薬技術の 進歩にともない非常に精選されて来た。なかんずくコロ イド，ソフト，の如き流動硫酸バリウムは造影剤として の性能及び取扱上においても特に精練されたものが市販 されるに至っている。

そこでこれを使用する立場から性能評価を行なって見 たのであるが，従来の沈降度試験やその他の単純な性能 評価の方法では困難になって来たので今回私共は沈降度 試験は言うに及ばずB型粘度計による粘張度試験，東芝 直続線量計によるバリウムの财収度試験，同じく特殊な 器具を製作し黒化度計による吸収度試験，物理的根拠に より作成した器具により測定した洷透度試験，そして外 国文献 (U.S.A. 1957. Saphir 及び Wile 氏)にもとずい $\tau \mathrm{pH} \times$-ターによる粒子試験 と, 物理及び化学的根拪 に順応して多角的性能評価を行なった結果従来の粒末バ リウムに比して流動硫酸バリウムは極わて高性能を有す ることを知ったし同時に個々の製品の特長を知ることが 出来たので要求面にそくした製品の選択が容易になった のでその結果を報告する。

88）バリウム注腸撮影における併用薬品及び時間撮影に วいて

中京病院 加 藤 芳 郎
磯 矢 和 之
大 落 隆 男
柴 田 澄 雄

\section{貿問}

バリウムの湦度はgrであらわした方がわかり易いと思 いますが\%であらわされた理由・（関西 二 宮）

\section{答}

30\%溶液とは局方Baでなく，われわれが使用したバリ トゲン（別にBa\%は図示）30\%溶液のことである。 （共演者 加 藤 芳 郎）

89）局部的気管支造影法の検討（第一報）

愛媛県汒新居浜療湌所（所長 山田良三）

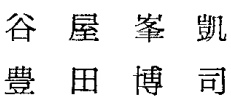

はじめに

現今気管支造撮法が簡単に行われるようになって，諸 々方々で盛んに行われておらます。特に胸部外科の領域
では，必ず行わなくてはならない手術前検査の一つとし て広く要望されるに至りましたので，一段と正確な読影 ま簡単で良い写真が出来たらとの考えの下に病巣光の局 部的な造影法を行って見ることにしました。

現在まで，われわれが行って来た造影法は，全肺葉注 入で，殆んぞ局部的な注入は行っていませんでしたがし かし確実に病柴への注入を計るには，局部的な造影の方 が，より効果的ではないかという考えが持たれておりま した。

そこで従来の経鼻道方式に変って, マッキン氏の搌頭 鏡を使用して,メトラ氏のゾンデーを注入し実験を行っ て見ました。その結果多少技術的には困難があるが割合 に良好な成積を収めたので，この機会に発表し，諸賢の 御検討を仰ぎたいと思います。

器具及び方法

器具

1. メトラ氏のゾンデー A. B. C.…...) 数本

2. マッキン氏脆頭鏡

3. 搌頭及び気管内森醉用噴霧器

4. 造影剂注入用注射器 $(20 \mathrm{cc}$ 用)

5. 造影修了器具入れ膿盈

6. スタイレット（ゾンデー注入用）

7. 枕（㬋頭部を水平にするため）

方法

先ず始めに $5 \%$ のコイン水液で，喉頭噴霧麻醉を行 う。大体 $3 \mathrm{cc}$ 程度の噴霧で充分であります。噴霧が終れ ば，被検者をあらかじめ水平にした透視台上に仰卧位に してやすませる，ての場合頭をもち上げて背中に小さな 枕を入れ喉頭部が水平になるように位置する。

続いて喉頭鏡で口蓋軟骨を持ち上げて，気管支口を見 出す。そこで，あらかじめ注人区域によって選んだゾン デーにスタイレットを通じて，グリセリンを塗ったメト ラ氏のゾンデーを㧴入する．挿入後は透視にょり，注入 部位の区域を選定して, 注入部位の気管支にまでゾンデー を挿入し紏創旁で固定する，続いて $20 \mathrm{cc} の$ 注射器に造影 凨を入れて，ゾンデーを通じて注入する，ての場合呼気 飞㹥休み吸気に注入する之刺激加無くて良い，注入後は 空気を入れて一寸圧力を加える。

注入が終予すればゾンデーを抜いて一枚の平面写真と 一枚の側面写真を撮って, 気管支造影は終了する。

成樍

今回の実験は特に経鼻道方式で注入不足が見られる患 者を対象として行った。 
良 い点

1. 造影剤による肺胞形成が全然ない。

2. 造影剤の注入量は各葉域によって異るが大体一葉 或8〜10 cc で従って少量でたりる.

3. 造影剂の注入量が少ないために患者の苦痛も少な く且つ排泄が早い.

4. 不必要部分への注入が少ないた診断し易い. （完全に注入しないとはいえない.）

5. 病夈部分への不足例が全然ない.

悪 点

1. 技術的に困難さがある.

2.ゾンデー挿入時に患者が一寸苦痛を覚える.

3.上葉支への注入時にゾンデーが深か過ぎると $\mathrm{S}_{3} へ$ の注入が因難となる。

おわりに

一般に下葉支への注入は普通の経鼻道方式においても 左右気管支の分肢点内にゾンデーが注入されておりさえ すれば，完全な注入は可能である，そこで特に上中葉域 への注入の場合を対象としてメトラ氏のゾンデーを使用 して実験を行い相当の成績を改めるてとが出来たと思う。 特に上葉支への注入に関しては経鼻道方式で注入不足の 患者を対象に㬰験を行っ見ました。しかしながら今回の 実験では, 応例件数が少なかったため, 完全に成助した とはいえないが，制合に良好なる成績が得られた。乙れ についてはなお今後の諸氏の御追試と御批判を載きたい と想って扮ります。

特に今度の実験から見て完全に明確に注入するために は,メトラ氏のゾンデーは，気管支が各人各様の形態を しているために，各人の気管支に合ったゾンデーを作っ て使用するのが当然の理であるが，一応左右葉域によっ て, 製作発売されているもので, 経鼻道方式による注人 困難例をも克服出来るととが解った。

\section{䓄問}

症例は幾例されましたか, 良い成績といわれるには少 くこも30例以上位されてからではどうでしょうか。

$$
\text { (関 西 二宮) }
$$

\section{答 5,6 例行いました。}

\section{㹕}

注入速度；測度？

メトラ使用について各症例についてゾンデに対し何か 手起加えておりますか？（茨城中央病院一色）

答

注入速度は大体注入終了は 10 秒 20 秒程度

メトラ氏のゾンデの使用に対しては全然ゾンデーに手
を加えて抢りません。

\section{補 足}

カテーテル嵒区域気管支まで挿人するのであるから特 に副作用の発現には十分の注意を必要とする。

発熱は従来の方法に比較して多く局所的症状として喀 痰増加が多く表われる。コカイン中毒も注意が必要で ある。

(青木座長)

\section{意 見}

質問者もまた演者も共に医師側に立ったような問題で 討論することはわれわれ技術者のはすべきことでない。 よってわれわれは技術の向上のための問題を論議すべ ぎだ. (中京病院 加藤 芳 郎)

90）電場発光 X線映像増巾装置に使用するフォトコンダ クターの特性について

島津製作所中央研究部 西川邦夫

山本正之

\section{1）透視におけるブレンデの格子比の検討}

三重大学 中 村 実

高圧撮影の進歩と共に透視時においても比較的高い電 圧が用いられるような傾向にあり，使用するブレンデも 適当な格子比の物を選定する必要があると考えて以下の 実験を行ったので報告します。

Slid(1)

実験に用いたものはスライドに示すでとき構造の MS リスホルムブレンデでありまして,格子比 $6: 1,8: 1,10: 1$ で各々透視用として $65 \mathrm{~cm}$ で Focusingしてあり，その 他の条件は同じこれら 3 種のブレンデを使用して, 散乱 線付加黒化率, テストチャートの弁別能, 被儤線量, 及 び実写等について比較実験を行いました。

Slid(2)

透視において各々のブレンデと管電圧を変化して，螢 光板の輝度を photo, maltiphier(931A)によって常に一 定となるように管電流を調整して実験しました。まず被 曝線量を測定し，格子比をパラメーターとして表わしま すと左の図のようになります。また右の図は螢光板の照 射野 $\left(35 \times 35 \mathrm{~cm}^{2}\right)$ に打ける線量を $100 \%$ として，任意の大 きさに紋り込んだ時の線量を百分率で示しました。

Slid(3)

ての図は脸部透視を仮定して $10 \mathrm{~cm}$ アクリルファント ームの中にビニール管直径 $(1 \mathrm{~mm} \sim 10 \mathrm{~mm})$ の物を插人 して弁別可能な限界を観祭して見ますと Slid(4) 